\title{
Gender Quota: Travails of the Women Reservation Bill in India
}

\author{
Samina Parween \\ (Political Science, Aligarh Muslim University, India)
}

\begin{abstract}
In India the Women Reservation Bill (WRB), which seeks to reserve 33\% seats for women in states and national legislatures, has been pending in parliament for several years; all major political parties have expressed commitment to it and it continue to be debated fiercely, though it has not been passed in Lok Sabha yet. Indian government has made various attempts at Gender Quota reforms. Quota for women in representative institution has long been debated in India. They first appeared in 1935 as part of the government of India Act, disappeared in 1950 as per the provision of the new constitution, and resurfaced again in 1988 as part of the government of national perspective plan on women. Finally it appeared in the form of 81 amendment bill commonly known as WRB in parliament on 1996.This paper is an attempt to examine the career of women reservation bill in parliament, which is striking for the high drama and rhetoric of women's right that has accompanied it, the passionate opposition to the bill being generally characterised by its supporters as anti women, patriarchal and so on.
\end{abstract}

Key words: Gender Quotas, Origin of reservations in India, Women's struggle, WRB in Parliament.

The legacy of the British rule which led to the partition of India into India and Pakistan coloured the first debate on quota in India. ${ }^{1}$ It has been believed that the intention of the Britishers behind this policy was divide and rule. However, if we seriously study the history of men the principle of divide and rule was really devised by Brahmins in India, who framed laws and rules on the name of dhamma and Brahma, to divide society vertically and horizontally and exploit large number of people- deprived, poor, ignorant, and divided so that a few on top may continue to enjoy the good things of life, power prestige and privileges. And when the Britishers came in India they took the opportunity of divided India and started the policy of divided and rule. ${ }^{2}$

Thus however the quota policy firstly applied as policy in the government of India act 1909 and 1919 granting the due shares of all minority groups, including Anglo Indians, Christian, Muslim, Sikh and depressed classes, as strategy for creating divisions within the movement. ${ }^{3}$ Thus the first quota were the part of the British administrative regime in India. The matter of reservation was also discussed by Britishers in round table conferences and provisions were made in the form of communal award of 1932 in spite of opposition by Mahatma Gandhi. The official stand of Indian National Congress under the leadership of Mahatma Gandhi was to oppose quota, particularly quota based on caste and religion. The British government, however, introduced quotas for a range of minorities under the government of India act of 1935. Thus the quota first appeared in a proper way in 1935 as part of the government of India act.

Independence came with the partition of India in August 1947. After independence the Dalit leader Ambedkar articulated the need of quotas for lowest castes and tribes and this was enshrined in the constitution of India in the form of Ninth Schedule and in Article 330 and $331 .{ }^{4}$ So the provisions of reservation came as an exception to the Fundamental Right to equality in favour of the Schedule Caste who suffered deep and entrenched social prejudice against them and Schedule Tribe who were physically detached from the mainstream of society and potentially faced the same facts as Schedule caste.

On the issue of women, it was believed that the recognition of women as equal citizens by the constitution and the provision of Fundamental Rights to them would automatically lead to equality in actual political life. It was assumed that such constitutional provision would take care of the various issues that had been the cause of women's subjugation for centuries and pave the way for their development. Earlier it was viewed that women's upliftment would come only after the achievement of freedom.

However, these assumptions could not prove totally right. The number and level of women participating in politics and playing an active role remained insignificant even after sixty seven years of independence. Women are still vastly under- represented in parliament and States legislative assemblies. In fact, the equal rights given to women in the constitution have little weightage in practice as seen from their poor representation in lok Sabha, at national level it constitutes only $10 \%$ female representation.

Quota for women in representative institution has long been debated in India. ${ }^{5}$ They first appeared in 1935 as part of the government of India Act, disappeared in 1950 as per the provision of the new constitution, and resurfaced again in 1988 as part of the government of national perspective plan on women. ${ }^{6}$ Actually, the issue of quota for women came up during the course of nationalist movement in the $1920^{\text {th }}$. The women's movement came out strongly against on quotas on the ground of equal citizenship right. ${ }^{7}$ In terms of the history of women's 
movement the early decade of the $20^{\text {th }}$ century mark the acknowledge beginning of fresh phase in women's organising. 'The education experiment of the late $19^{\text {th }}$ and earliest 20th century' it is said "produced a new woman with interest that went beyond the house hold". 8

Thus the first policies to institute quota for women appeared in India in the 1930s, as the British government moved to include women among list of groups that were guaranteed representation in the colonial regime. The nationalist movement however condemned this solution as 'divide and rule' strategy that sought to undermine the common identity of all Indians. ${ }^{9}$ The public official language of politics especially before colonial government had to be a language of equality and for the fundamental right of citizenship irrespective of caste, sex, religion and greed. This opinion was supported by the prominent and leading women organisation of the time All India Women Council (AIWC), Women Indian Association (WIA), National Council for Women $(\mathrm{NCW})$ of India and also supported by Indian National Congress and Muslim League. ${ }^{10}$

It is however important to note that the opposition to the idea of quota was not restricted to the question of women alone. The AIWC in their resolution expressed their opposition to the British communal award of 1932, which sought to provide electorate for minorities group.

The issue of reservation for women had come up again in the constituent assembly; and this was again rejected by women members, representing the All India Women Congress, as demeaning the women struggling for equality with men in all sphere of life. The suggestion was also seen to underestimate the strength of women to compete as equals. ${ }^{11}$ For this reason, after independence, the newly drafted constitution abolished special seats for women in the interest of recognizing fundamental equality between men and women. ${ }^{12}$ Proposal to reserve seats (quota) for women while not included in the constitution, resurfaced again in 1957 in the context of discussion regarding a new system of local government, when the committee in charge of making recommendations, advised that all local councils will include at least two women. The final version of the law passed in 1959 did not make any specific requirements regarding women, but did empower local leaders to nominate some to the council if no women were elected directly. Thus despite the existence of some policies, the faith both among women's group and within the congress party that women would be elected to parliament without the need for special intervention meant that no initiatives were taken in this area in the years following independence. ${ }^{13}$

The second phase of quota politics begins in 1970s and 1980s. This, of course, is also the time when international organisations such as United Nation (UN) were beginning to recognize the importance of women in public life, leading to the UN conference on women held in Mexico on the status of women worldwide and declaration of the decade for women in 1975. The state in India responded to UN extortions and some uneasy about women's status within Indian society among women's group by establishing the first Commission on the Status of Women in India (CSWI) in 1972.This once again debated the reservation issue. ${ }^{14}$

However Indian government setup this committee to examine the social, economic and political standing of women in India. Committee toured throughout country and interviewed more than five hundred women in each state, the women's group with whom it met repeatedly raised reserved seats as the only visible solution for improving women's access to political office at the local, state and national level. The committee included these arguments in its final reports, but a majority of the CSWI members rejected the step on the ground that the reserved seats were retrogressive measure that contradicted the principle of equality in the constitution. ${ }^{15}$ The committee conceded, however, that reservation might be necessary at local level to ensure the interest of rural and poor women. For this reason it recommended that women's council, elected directly by local women, be formed in every village and given the responsibility of managing and administering women's and children's welfare and development programme as part of the broader system of local government. At the same time, it encouraged political parties to increase the proportion of women among their candidates, using part based quota if necessary. ${ }^{16}$ But on the question of quota for women at state and national level the CSWI by majority decided to uphold the position taken in the constituent Assembly. ${ }^{17}$

These recommendations were passed on to the state government, but mostly responded negatively and therefore took no concrete actions to facilitate women's access to political office. ${ }^{18}$ Several states however returned to the issue of women representation during debates over local government reform during the 1980s, interestingly some quotas had adopted by few states governments across the political spectrum, i.e. the Janta party government in Karnataka reserved 25\% of seats for women in village and district councils in 1983; the Telugu Desam party government in Andhra Pradesh reserved 9\% of seats for women in urban corporations and district, block, and village councils in 1990; and the communist party government in Kerala reserved 30 percent of seats for women in district council in $1991 .^{19}$

Amidst of these grassroots development, Rajiv Gandhi came to power in India, after assassination of his mother Indira Gandhi in 1984, and identified women's status as a greater priority issue, and agreed to reopen the CSWIs recommendations on Panchayat that is the female representation in political institutions especially at the grass-roots level needed to be increased through a policy of reservation of seats for women. Consequently his government responded with a National Perspective Plan (NPP) in 1988 for women. ${ }^{20}$ The NPP in its first draft, 
acknowledge the problem of under representation of women and recommended $30 \%$ reservation for women in all elective bodies from Panchayat to parliament. But the committee encountered by a great deal of opposition to the idea of mandating reservations at all levels of government. So after the consultations with women's group and the women's wing of the various parties, the NPP therefore decided to peruse reservation at local level first and then, once women had gained experience in elected politics, to seek to extend reservation to the national level. $^{21}$

Therefore NPP (1988-2000) in its final draft recommended reservation of at least 30\% of the total seats for the women in the local government institutions. Subsequently states like Karnataka and Gujarat implemented some form of reservation for women in Panchayati Raj Institutions. ${ }^{22}$ These developments towards the quota system for women's representation reflect some wider political processes in the country. By the 1990s the women's movement in India had begun to engage with the state at both the local and national level. ${ }^{23}$ Women's group were started to being consulted by the government on issues of welfare, culminating in the establishment of the women's National Commission in1992. ${ }^{24}$

Following the recommendation of NPP by Rajiv Gandhi government, who regarded women as a new constituency and addressed the issue of India's modernity by focussing on the position of women in the country, the 1992 provision of reservation of seats in local government for women under the $73^{\text {rd }}$ and $74^{\text {th }}$ amendments to Indian constitution was a key intervention by his government. ${ }^{25}$

The $73^{\text {rd }}$ and $74^{\text {th }}$ Constitutional Amendment provided decentralisation and one third reservation for women nationwide in local bodies respectively. In first election after the new legislation came into effect, nearly one million women entered in political institutions, shattering the myth that Indian women are fundamentally disinterested in political process. ${ }^{26}$ The $73^{\text {rd }}$ and $74^{\text {th }}$ amendment of Indian constitution was nearly a major milestone for empowering the Indian women. At current time there are approximately 260.000 Panchayat representatives in India, out of which around 75.000 are women making it the largest number of elected women in the world. ${ }^{27}$ The impact of this legislation has been fruitful and has empowered women both politically and socially. The relatively quick passage of this reform inspired women group in India to join together to press for the immediate extension of reservation to the state assemblies and the National Parliament.

However, here, it is important to note that the 1990s have been water shed year in India's history, a time of transition, when the nation state was subjected to unprecedented pressure from without and within. This has been the decade of liberalization of the economy, the Anti-Mandal agitation against the extension of reservations to the other backward classes, and the emergence of lower and backward castes parties such as Bahujan Samajwadi Party (BSP) and the Samajwadi Party (SP). This was also the decade of the demolition of the Babri Masjid and the ensuring right, and the rise to dominance of Bhartiya Janta Party, led coalition government at the centre. It is in this context that the $81^{\text {st }}$ women reservation bill for one third reservation for women was first tabled in Parliament on 12 September 1996, and was soon mired in the conflict over the demand for special quotas for the women of other backward classes and minorities. ${ }^{28}$ Here it's also important to note that for coming 1996 national election all the major political parties including Congress party, Janta Dal Party, Bhartiya Janta Party the Samta Party and Both communist party CPI and CPI (M) responded by incorporating quotas demand in their manifestoes for 1996 elections, and the United Front Government, a new coalition led by Janta Dal identified women reservation as priority issue in its common minimum programme. ${ }^{29}$ But the 1996 elections resulted in parliament with fewer women contained than the previous three parliament i.e. women contested only $11 \%$ of the total seats, and only 36 women became members out of total of 545 as compared with 44 in previous parliament. ${ }^{30}$

It may be therefore the newly elected government moved towards quota for women, introduce $81^{\text {st }}$ Amendment Bill, commonly known as the Women Reservation Bill (WRB), it seek to reserve one third of all seats for women in the Lok Sabha and the State Legislative Assemblies. The first WRBs have been referred to joint select committee of the Indian Parliament due to differences among party about the detail of the proposed bill. The debate also on the bill in the Indian press reveals that there is lack of political general will among parties to pass the bill which would ensure this quota for women. Although women's group have largely supported the measure though some important voices within the women's movement have spoken out against the bill. After submission of the recommendation of by the committee on December 9, 1996, the bill could not be passed perhaps because it did not recommend for a sub quota. WRBs again tabled for discussion on May 16, 1997 but lapsed as the Lok Sabha was dissolved. ${ }^{31}$

As 1997 onwards, women's organization and the National Commission for women launched a new campaign calling for passage of the bill in the coming session of parliament. They noted that quota were one of the few issue to bring women together across the political spectrum, because most had personally witnessed discrimination in candidate selection procedures and thus had eventually come to realize that reservation were the only way to ensure women fair access to politics. ${ }^{32}$ Therefore, on July 14, 1998 WRB again brought before the house as the $84^{\text {th }}$ amendment bill by BJP government and leave of the house to introduce the bill was granted on December 14, 1998. But its passage was stalled in view of strong opposition more on less on similar grounds 
and it lapsed following the dissolution of the $12^{\text {th }}$ lokSabha. Again it introduced in coming Lok Sabha as $85^{\text {th }}$ amendment bill, on December 221999 re-enacting the earlier scene of discussion and pandemonium and the bill seem to have died an unnatural death. ${ }^{33}$

However, by far the most powerful objection came from OBC men, who argued that reservation for women would only strengthen upper castes dominances, because the women likely to benefit from them were likely to be those with greater social and educational opportunities. Rather than rejecting reservation altogether, they called for the policy to include a sub reservation for $\mathrm{OBC}$ women. Muslim leaders soon echoed these arguments claiming that the existing proposal would promote mainly Hindu if the policy did not specify sub reservation for Muslim women. other minorities groups follows with similar demands, including SC leaders who were apparently unaware that a sub reservation for sc women already appeared in the bill, but perhaps sought to garner extra seats from the women quota, rather than yield seats to women from the existing sc quotas. On the basis of demanding quota within quota three times the bill could not be debated.

After repeated delays, the government sought to introduce the WRB for the fourth time on May 2003, but it also strongly coming to oppose again strongly from Rashtriya Janta Dal (RJD) and Samajwadi Party which continued to insist that the bill be revised to include sub quotas for OBCs and Muslims. When the parties still could not agree by March 2004, Vajpayee blamed main opposition from Congress for stalling the WRB and assured voters, as election approached, that the BJP-led National Democratic Alliance would ensure passage of legislation if voted into power again. Congress leader Sonia Gandhi responded by pledging that her party if elected, would pass WRB. Women group called both party hypocrites, pointing out that women formed less than $10 \%$ of the candidates on their list.

Subsequently, the May 2004 elections registered an increase in support for Congress, the party returned to power as part of the united progressive alliance. By the following years however the government and the congress party appeared to distance themselves from this proposal the WRB. The United Progressive Alliance (UPA) government has recently decided to float a new bill to increase the number of seats and reserve 33 percent of them for women in both the Lok Sabha and State Legislatures. It was decided to introduce this bill in the next parliamentary session, according to Shiv Raj Patil, the Union Minister for home affairs. Although by spring Shivraj Patil as home minister said that $19^{\text {th }}$ of the 20party he had spoken to had agreed to create more seat in the legislature and reserved them for women. ${ }^{34}$

In early 2007 the Prime Minister again said that the bill would be introduced as soon as consensus was built on the issue. And finally when it begun criticizing the UPA government for not delivering it promises with regard to the WRB as the government moved to table the bill on May 2008. Moreover finally the long awaited $33 \%$ WRB was tabled in Rajya Sabha on 6 May 2008. The WRB was enthusiastically welcomed by women politician across the political parties. ${ }^{35}$ Yet the WRB has failed to pass in Lok Sabha for last the sixteen years. The bill was finally cleared in Rajya Sabha in March 2010. Although the Upper House introduced the bill, it will not be properly legislated on until it passes through the lower house which is where the quota will be implemented. However, passes the bill in Rajya Sabha is a progressive and substantive step towards the political empowerment of women in India. The fact that it has taken nearly a decade and half for this legislation to be passed just in upper house of parliament, stands testimony to the stubborn opposition against it from various quarters. ${ }^{36}$

As the WRB has not yet been adopted at the national level, women representation in the Lok Sabha currently stands at only $10 \%$. Among the few female candidates selected by the parties most come from higher caste, privileged class backgrounds and prominent politicians families. Evidence from local government, where reservation have been in place for more than 15 years, suggested that these selection pattern might changed dramatically with one third reservation at the same time that it reveals the various positive and negative consequences that reservation might have on women's opportunities for influencing public policy. ${ }^{37}$

Above we saw that the career of women reservation bill in parliament is striking for the high drama and rhetoric of women's right that has accompanied it, the passionate opposition to the bill being generally characterised by its supporters as anti women and patriarchal. Some of the comments and phrases decrying the derailing of the bill are illustrative: 'a predominantly male parliament developed a cold feet'; 'Sansad par Kaabiz purush satta'; 'parliament was divided into men and women, the former all opposed to the women reservation bill'; 'parliament is like an all male club and women feel like an unwanted intruder'; 'on caste based argument in defence of male domination. ${ }^{38}$

It is now evident that we find the two sets of argument for and against on WRB. There is feminist argument for and against reservation for women, and caste based argument for and against.

A feminist argument for reservation comes from left parties and women's group in terms of creating equal opportunity in order to make real the formal equality given by the constitutions. And the argument against the reservation is made by a prominent writer Madhu Kishwar, the editor of Manushi (which calls itself a journal about women and society), and by the Sethkari Mahila Aghadi (SMA) a peasant women organisation founded in 1996. Their broad argument has to do with the concern that reservation will only bring to fore the biwi-beti 
brigade. Because leaders are likely to resort to fielding's their mothers, sisters or wives to ensure that the women's quota stays within their caste control and women legislators do not pose any challenge to their power. ${ }^{39}$ The SMA in an open letter to MPs said that quota for women, is being pushed by in the creamy layer. Menonp172

The next sets of argument are on caste based; take position for and against reservation explicitly and implicitly particularly from political parties. The most reviled, explicitly caste based opposition to WRB has been the derogatory reference of Sharad Yadav to the short haired women who would overrun parliament. It mean that reservation for women would radically alter the composition of parliament in favour of upper class and upper caste the term 'parkati mahilayen' in this context drawing upon a common stereotype of westernised and elite women. ${ }^{40}$

It is not surprising then that the OBC Dalit leaders are highly suspicious on the WRB. The three parties namely, Samajwadi Party (SP), the Rashtriya Janta Dal (RJD) and the Janta Dal United (JDU) is demanding a quota for weaker sections within one third quota. For Instance, in an interview Mayawati a BSP leader demanded that there should be 50\% reservation for women and within this, separate reservation for backward castes and minorities. Mulayam Singh Yadav of the Samajwadi party has consistently opposed the bill; saying that in its present forms it is anti minority and anti Dalit. The Sp and RJD have threatened to withdraw support to the riling progressive alliance (UPA) if the government forces the legislation in its present form. ${ }^{41}$ The RSS had strongly opposed it on the ground that it would disrupt family life and social harmony.

Most interestingly, Uma Bharti of the BJP herself from a backward caste has taken a position opposed to that of her party, unlike Sushma Swaraj the upper caste BJP leader most vocal in support of the bill.Thus when the WRB being tabled by the United Front Government first time in 1996, it was Uma Bharti who first raised objection to the bill. She makes a clear feminist argument for reservations, while asserting that a backward caste or Dalit women is doubly oppressed, and so should have place within the quota. ${ }^{42}$

Some leading Muslim women citizens who described themselves as secular activists have expressed their support for the Women's Reservation Bill and criticized those Muslim clerics who have wondered why reservation should be extended to women.

Among the women activist who have hailed the move to provide 33\% reservation of seats to women in the Lok Sabha and State Legislature are: Naish Hasan of the Bhartiya Muslim Mahila Andolan, Lucknow; Shabnam Hashmi of Anhad, Delhi; Zakia Soman, Bhartiya Muslim Andolan, Delhi; Noorjehan Safia Niaz of Bhartiya Muslim Mahila Andolan, Mumbai Aziza Ahmed who is a human rights lawyer based in New York. ${ }^{43}$

In a statement, the activists have said that the bill is "the first towards equality and justice for women". They have further said:

"We believe once the bill is adopted there can and will be democratic processes through which space and genuine participation for excluded women including Muslim women can be worked. However, it is shocking the way some religious leaders are opportunistically using the debate on the bill to make reprehensible statements in the national media about women and their role in society". 44

Susheela Gopalan members of the Communist Party of India (Marxist) (CPI (M)), well known for her efforts to organise women and women workers, remarked in an interview in 1999 thus: Initially I was against reservations but today there is no option... when women become Panchayat members they acquire earning capacity and become independent...They develop confidence and can be trained as potential candidates for Assembly and Parliamentary elections in the future. ${ }^{45}$

Although the women's reservation Bill, which aims to reserve 33\% in the National and State legislatures for women, has not yet been passed by the Lok Sabha, but the impact of reserving one third seats in Panchayat raj institutions for women has certainly been immense. The biggest success of panchayati raj in India is that it has politically and socially empowered women. Though under the panchayati raj system only $33 \%$ of seats are reserved for women, Bihar took the bold step of pushing up the figure to $50 \%$ in 2006. Elected women now occupy $54 \%$ of seats in Bihar's Panchayat. Bihar examples were followed by Sikkim, which increased its reservation for women to $40 \%$ and held elections in January 2008. Chhattisgarh, Madhya Pradesh, Rajasthan and Uttarakhand have also passed law increasing the reservation for women in Panchayat to $50 \%{ }^{46}$

Recently, on the eve of International Women's Day a debate took shape on women issues in Lok Sabha, government announced that they will take precedence over quota bill. Especially the two political parties the DMK and CPI (M) raise a strong voice for passage of the legislation to provide 33\% quota for women in Lok Sabha and state assemblies.

As soon as the house met for the day, Hamid Ansari Chairman of the Rajya Sabha appreciated the untiring commitment and persistent efforts of women said that "Today though women have made remarkable progress in economic, political and social sphere, gender equality remains a distant dream". Meira Kumar, speaker of the Lok Sabha said on this eve "Let us on this day re-dedicated ourselves collectively to work steadfastly towards achieving an equal and human environment for women". ${ }^{47}$ 
Although the WRB for state and National level has not been yet approved in Lok Sabha, evidence from its implementation at the local level reveals that systemic reforms alone can produce dramatic changes in the numbers of women elected to political office, precisely because the mechanism of reserving seats means that seats are literally set aside for women. Insights from the local level, however also cast light on how opponents may still draw on existing practices and norms to de-legitimise women as political actors and thus undermine their effectiveness as policy makers. Indeed, men in several local councils have devised alternative strategies for excluding women, especially against women from underprivileged social backgrounds, to ensure that they are not present in deliberations despite the fact that seats are especially reserved for them. These patterns suggests that systemic reforms may be extremely effective, but call attention to the need for accompanying practical and normative reforms to support broader goal of systemic change. ${ }^{48}$

\section{References:}

[1] Shirin M. Rai, The gender politics of development (Delhi: Zubaan (an imprint of kali for women) 2008$) 92$

[2] Bhagwan Das, Movements in a history of reservations, Economic \& political Weekly, XXXV (43-44) 28 ${ }^{\text {th }}$ October 2000, 3831-3834, ws-31-34.

[3] Mona Lena Krook, Quota for women in Politics (New York: Oxford University Press, 2009$) 84$.

[4] Shirin M. Rai, Gender quotas and the politics of empowerment - a comparative study, in Drude Dahlerup (Ed.), women quotas and politics, (Rutledge: New York 2006) 223-245.

[5] Nivedita Menon, Elusive Women: Feminism and Women's Reservation Bill, in Meena Dhanda (Ed.), Reservation for women,(New Delhi: Women Unlimited (an associate of kali for women) 2008), 59.

[6] Mona Lena Krook, n.3, 84.

[7] Shirin M. Rai, n.4, 224.

[8] Mery E. John, Alternative modernities? Reservation and women movement in $20^{\text {th }}$ century India, Economic \& Political Weekly, XXXV (43) 28 October 2000, 3822-3829.

[9] Mona Lena Krook, n.3, 103.

[10] Vasanthi Raman, The implementation of quota for women: the Indian experience, Paper presented for workshop, in Jakarta Indonesia, Hosted by IDEA on 25 September 2002, online available on http://www.idea.int.

[11] Menon, Nivedita. n.5, 159

[12] Mona Lena Krook. n.3, 103.

[13] Ibid, 88.

[14] Rai, M. Shirin, n.1, 96.

[15] Ibid, 96.

[16] Mona Lena Krook, n.3, 89.

[17] Nivedita Menon, n.5,159-160

[18] Mona Lena Krook, n.3, 89.

[19] Lubna Yousuf, Politics and prospects of reservation of women in India, Indian Journal of Politics, XLIII, (1) January - March 2009, 177-186.

[20] Mazumdar, Vina. (1997) 'historical soundings’. Seminar, September 1997, No. 457, 14-19.

[21] Mona Lena Krook, n.3, 90.

[22] Nivedita Menon, n.5, 160.

[23] Shirin M. Rai,n.1,.96.

[24] Shirin M. Rai, Mainstreaming gender, democratizing the state, Institutional mechanism for the advancement of women,(U S A: Transaction publishers 2007) 180.

[25] Shirin M. Rai, n.1, 96.

[26] Paxton, Pamela and Melanie M. Hughes, women politics and power: A global Perspective (New Delhi: Pine Forge press 2007)250.

[27] Shahin Razi, Empowered women, Empowered nation, Yojna, issue June 2012.

[28] Mary E. John,Women in Power? Gender Caste and politics of local urban governance, Economic \& Political Weekly, XLII (39)29 September 2007, 3986-3993.

[29] Kishwar, Madhu, Women and politics: beyond Quotas'. Economic \& Political Weekly, 31(43), 26 October 1996, $2867-2874$.

[30] Shirin M. Rai, n.5,115

[31] Panday, Snehlata, Political empowerment of women (Delhi: Raj 2002) 43.

[32] Mona Lena Krook, n.3, 93.

[33] Snehlata Panday, n.31, 43-44.

[34] Lalita Dhar Parihar, Women and Law, from impoverishment to empowerment, (LuckNow: Eastern Book Company 2011 ) 91.

[35] Vaishali Diwakar, Maya Machhindra and Amar Jyoti: Reaffirmation of the Normative, Economic \&Political Weekly, XLIV (17) 25 April 2009, 75-84.

[36] Prasenjit Bose, Women's Reservation in Legislatures: A Defense'. Economic \&Political Weekly, XLV (14), April 3 2010, $10-13$.

[37] Mona Lena Krook, n.3, 100.

[38] Nivedita Menon. n.5, 162.

[39] Madhu, Kishwar, women and politics: Beyond quotas, Economic \& political weekly, 31(43), 26 October 1996, $2867-2874$.

[40] Nivedita Menon, Recovering Subversion: Feminist politics beyond the Law, (Ranikhet: permanent black 2004) $173-174$.

[41] Lalita Dhar Parihar. n.34,90.

[42] Nivedita Menon. n.40, 174

[43] Lalita Dhar Parihar, n.34, 91.

[44] Ibid.

[45] J. Devika and Binitha V. Thampi, Beyond Feminine Public Altruism, women leaders in Kerala's Urban Bodies, Economic \&Political Weekly, XLVII(17) 28 April 2012, 76-83.

[46] Nupur Tiwari, Rethinking the rotation term of reservation in Panchayat, Economic \& Political WeeklyXLIV (5)31 January 2009, 2326.

[47] The Hindu, 9 March 2013, 10

[48] Mona Lena Krook. n.3,105. 